\title{
LLANA, RAMAT I OLI. EMPRESES EN ÈPOCA MEDIEVAL: NIVELL D'INVERSIÓ I COSTOS A LA DRAPERIA (EL COMTAT AL SEGLE XV) ${ }^{1}$
}

\author{
Josep Antoni Llibrer Escrig \\ Departament d'Història Medieval. \\ Universitat de València
}

\begin{abstract}
Resum: L'article analitza les característiques de les empreses draperes que s'hi van anar formant durant el segle XV a l'àrea del Comtat. En un conjunt de viles de tamany mitjà, com ara Cocentaina, Ontinyent o Alcoi, s'hi va produir una especialització productiva en el sector de la llana basada en la multiplicació de petites unitats de producció, de petites i mitjanes empreses. Estudiem aquestes empreses, tot diferenciant els negocis i les inversions, on un petit grup d'artesans més emprenedors tendien a centralitzar i gestionar aquesta activitat tèxtil mitjançant la seua actuació al mercat de la llana, del ramat i de l'oli.
\end{abstract}

Paraules clau: Empreses tèxtils / draperia / ramat oví / oli / El Comtat / segle XV.

Wool, sheep and oil. Medieval enterprises: investment level and cost in the woolen industry (El Comtat over the 15th century)

Abstract: This article studies the role of a textile enterprises in the region of El Comtat, Kingdom of Valencia, during the fifteenth century. In some small towns, Cocentaina, Ontinyent or Alcoi, there was a textile specialization based on the multiplication of artisans and small workshops or small enterprises. We study directly the artisans and their enterprises, their businesses and their investments. A small group of craftsmen were able to centralize management of textile activities through direct participation in the wool, sheep and oil markets.

Key words: Textile enterprises / woolen industry / sheep / oil / El Comtat / $15^{\text {th }}$ Century.

\section{PLANTEJAMENT I METODOLOGIA}

Empresaris i empreses en època medieval? Potser el lector trobarà atrevida o fins i tot anacrònica aquesta associació inicial. Podem parlar realment d'empreses als segles medievals? És lícit aquest terme per aquests periodes precapitalistes? Constituïen els artesanals i els mercaders medievals autèntiques empreses per desenvolupar els seus negocis? Els exemples que oferirem a continuació ens ajudaran a resoldre aquestes qüestions, però cal en primer terme, i açò és fonamental, precisar conceptes per situar-nos en els punts i els contextos a tractar.

L'any 2002 es va celebrar a Venècia un interessant congrés internacional, La storia dell'impresa nella lunga durata: continuità e discontinuità, que no feia sinò confirmar l'ac-

Data de recepció: 17 de juliol de 2014 / Data d'acceptació: 14 de novembre de 2014.

1 Aquest treball s'inclou dins el projecte d'investigació "Identidades urbanas Corona de Aragón-Italia: redes económicas, estructuras institucionales, funciones políticas (siglos XIV-XV)", ref. HAR201128861, finançat pel Ministeri de Ciència i Innovació (2012-2014), i dirigit pel Prof. Paulino Iradiel. 
tiva presència de la business history en molts àmbits de la historiografia arreu d'Europa. Les contribucions que s'hi van escoltar a la Ca'Foscari veneciana, i que van ser publicades un any després al número 14 de la revista Annali di Storia dell'Impresa, confirmaven no solament aquesta fructífera tendència sinò també l'emergència d'un món preindustrial farcit d'iniciatives empresarials de tota mena i dins tot tipus de sectors econòmics amb formes i estratègies de producció força variades i polivalents, que tendien a adaptar-se a diferents àmbits i escales (Amatori, 2003). Des de les grans empreses internacionals de producció i comercialització de béns de consum o els grans consorcis financers italians, i per només referir-nos al periode medieval, amb noms que tothom recorda como ara els Datini, els Medici o els Fugger, passant pels empresaris de la llana de les ciutats toscanes, per les nombroses empreses d'extracció i producció de metalls, o per les petites empreses d'àrees rurals encarregades de la producció de tot tipus de béns. Descobrim al capdavall tot un munt d'iniciatives, negocis i inversions que, tot i escales diferents, no fan sinò parlar-nos de les diverses formes de producció. I en aquest darrer punt està la clau d'allò que volem analitzar: com en l'àmbit rural i semiurbà baixmedieval, tota una sèrie d'estratègies empresarials humils i limitades però força operatives, permeteren aprofitar les potencialitats de les viles i les comunitats rurals per donar lloc en alguns casos a importans processos de desenvolupament regional (Verna, 2013, 77-88). En realitat, l'escala més petita de les iniciatives econòmiques que anem a estudiar ens allunyen lògicament de les grans empreses i empresaris com els citats més amunt, però els seus negocis, d'escala supralocal i comarcal, tendien també a articular-se a través de petites empreses sovint de caire i arrel familiar, d'obradors i botigues domèstiques, però que desenvolupaven inversions genys menyspreables i estratègies, com ara la formació de tota mena de companyies, que ens parlem del caire emprenador de molts artesans i mercaders d'àmbit rural, artesans i mercaders que sovint esdevenien petits hòmens de negocis. Emprenedors que no feien sinò activar produccions, distribucions i mercats locals i comarcals.

Però caldria, abans que tot, oferir una definició acurada del concepte "empresa", pel fet que estem aplicant-lo des del principi i sense cap matisació prèvia a nombroses activitats econòmiques dins el context econòmic baixmedieval. Recordem, com diu Malanima, que la gran empresa capitalista contemporània, la que tots hui pensem, és només un tipus d'empresa, una de les moltes formes que l'empresa ha assumit al llarg de la història, però no defineix, ni pot definir, el concepte "empresa". En realitat, per empresa cal entendre la institució o l'organització en la qual es combinen factors de producció -o inputs- amb la finalitat de transforma-los en béns econòmics, uns béns que poden ser mercaderies, béns semielaborats o serveis (Malanima, 2003, 160). Cal precisar, per altra banda, que aquesta definició té un marcat sentit microeconòmic, i que s'apropa a la realitat productiva primària i bàsica. És per aquesta raó que nosaltres farem un exercici d'apropament a aquesta realitat, i ho farem mitjançant un recorregut microhistòric, un recorregut que ens permeta d'apropar-nos als petits obradors, als petits negocis per reconstruir tot un munt de petites i mitjanes empreses artesanals i mercantils.

Assumint aquesta perspectiva d'anàlisi, i entenent per tant que l'empresa és present a tot arreu del món medieval, és evident que el nucli que conformava l'origen d'una empresa era sempre l'escala familiar. La família, tot seguint la definició més amunt apuntada, constituïa una empresa pel fet que al seu si activava uns factors de producció amb la finalitat d'obtindre uns béns; en la mesura que dins la unitat familiar es poseïa o es prenia en arrendament terres, eines, màquines -com ara un torn, un teler, un molí, una almàssera $\mathrm{o}$ 
un forn de terrisseria-, amb les inversions de capital necessàries i la mà d'obra intrafamiliar adequada, es posava en funcionament una petita unitat empresarial, limitada sovint als espais d'una vila o d'una comarca, però que permetia la producció, l'intercanvi i, sobretot, l'activació de nombroses iniciatives i de la vida econòmica local. L'escala petita que estava associada a la major part d'aquestes empreses familiars no ens pot fer oblidar, en primer lloc, la seua polivalència i, sobretot, la funció que aquestes duien a terme en el teixit econòmic local, $\mathrm{i}$ en els processos de desenvolupament de moltes àrees i regions de l'interior. En efecte, la multiplicació d'aquestes petites unitats de producció està a l'arrel de la formació i consolidació d'autèntics districtes manufacturers i industrials que, nascuts en aquests periodes baixmedievals, s'hi van consolidar a l'època moderna (Iradiel, 1986; Navarro, 1999; Llibrer, 2010).

I és ara quan cal fer referència a l'espai que centrarà bona part de la nostra anàlisi, i que esdevé per a nosaltres autèntic observatori de privilegi per a reconstruir i estudiar aquestes petites però alhora polivalents i dinàmiques empreses medievals. Anem a l'espai del centre-sud del País Valencià, a l'àrea conformada per les actuals comarques de la Vall d'Albaida, l'Alcoià i, sobretot, el Comtat, on a moltes de les seues viles, com ara Ontinyent, Bocairent, Albaida, Alcoi o Cocentaina, van sorgir durant tot el segle XV una gran quantitat d'empreses i d'iniciatives artesano-mercantils al voltant de la producció de teixits de llana i seda. Les anàlisis prosopogràfiques que ja hem desenvolupat en aquesta autèntica "regió industrial o manufactuera medieval" ens parlen d'una concentració de més de 600 obradors, que en molts casos constiuïen autèntiques empreses, i només per a la segona meitat del Quatre-cents (Llibrer, 2014, 47-103). A més a més, aquesta destacada concentració, que pràcticament no té comparació amb cap altre indret del País Valencià, ni tampoc de la Corona d'Aragó, excepte a les grans metròpolis (Navarro, 2003 y 2013), es complementava amb tot un seguit d'iniciatives -també de caire empresarial- sense les quals no hauria estat possible aquest desenvolupament manufacturer: parlem, per una banda, de l'articulació de diverses àrees d'aprofitament hidràulic per al tintantge i el batanatge dels draps al voltant dels rius Clariano i Molinar-Serpis, tot constituint una concentració de trenta-vuit molins drapers en funcionament a principis del segle XVI (Mira, 2000, 235-271; Mira, 2005, 70-75; Llibrer, 2012), i que ens parlen d'una producció anual d'uns 8.000 ó 10.000 draps (Llibrer, 2010, 193); per altra banda, la tradicional vocació oliera i ramadera d'aquestes muntanyes de l'interior valencià, va estar aprofitada per la iniciativa d'un important sector emprenedor local -d'artesans empresaris, al capdavall- per facilitar l'abastiment de les matèries primeres i, alhora, per posar en circulació els béns produïts en els mercats comarcals propers; perquè no oblidem, en definitiva, que aquesta ampla producció només s'explica des del vessant de la demanda (Llibrer, 2010, vol. I, 54-70).

Des del punt de vista metodològic, el recurs a la microhistòria i a l'anàlisi prosopogràfica que se'n deriva, serà fonamental per reconstruir negocis, iniciatives i empreses. Pensem, en efecte, que només amb la recollida sistemàtica d'informació i notícies econòmiques dels individus -dels artesans, dels mercaders- és possible apropar-se als obradors, a les botigues, a les formes i a les relacions de producció, també a les categories laborals, a les inversions, als negocis i, finalment, a les estratègies d'empresa. En el marc de la reconstrucció de les activitats econòmiques i els curricula laborals, la prosopografia ha demostrat ja la seua validesa (Narbona et alii, 1995; Narbona, 1999; Navarro, 1999), i més encara si fa referència a àmbits restringits, com ara a petites viles o comunitats (Llibrer, 2007, 2008, 2010). Per altra banda, el mètode prosopogràfic s'enriqueix amb la combina- 
ció de diferents fonts, per un costat les polivalents escriptures notarials, per altre, els llibres de la Cort del Justícia i els Manuals de Consell (Iradiel, 2011). D’aquesta forma, resseguir un artesà empresari o un mercader emprenedor és senzill en la mesura que els seus negocis i les seues estratègies el fan anar sovint des de la taula notarial, on signa contractes, comandes o compravendes, als volums del justícia, on denuncia els seus veïns -o és denunciat pels seus veïns- a causa dels seus negocis, i finalment als Manuals municipals on es recull amb freqüència la seua participació en la vida pública, o el desenvolupament de càrrecs dins la juraderia o la mateixa justícia com a prohom de la vila. I és que l'acció d'aquests empresaris o emprenedors no es limitava únicament a l'àmbit de la producció o de la comercialització, també aquest rol econòmic solia tenir un reflex en la res publica, en la vida de la comunitat (Navarro, 2014; Llibrer, 2013).

Només uns pocs exemples significatius, triats de molts altres que hem pogut documentar mitjançat el recurs a la metodologia prosopogràfica. Joan Sancholí, un actiu paraire-empresari veí de Cocentaina, localitzat entre els anys 1470-1495, es documentat primerament als protocols notarials duent a terme tota mena de negocis drapers i mercantils: compra llana en grans quantitats, ven draps, també ramat i d'altres productes com oli, vi i cereals; pren en arrendament les alqueries de Fraga, Benitaer i Benàmer; també l'impost de la primícia del Comtat; alhora, als llibres del justícia de la vila diversos artesans veïns confessen deure-li certes quantitats pel tintatge de diversos draps; es localitzat, a més a més, nombroses vegades als Manuals de Consell com a conseller, jurat, siser i com a administrador de l'hospital de la vila².

El mercader constestà Bernat Botet (1471-1495) ens apareix nombroses vegades als fulls notarials amb els seus negocis de compravenda de draps, oli i cànem; acudeix també a la taula del notari per adquirir diverses parcel·les i fins i tot un molí fariner de dues moles. Serà assidu als llibres judicials i als Manuals de Consell pel fet que desenvolupa el càrrec de justícia durant els anys 1470, 1476 i 1493.

El nom del paraire Joan Sanç (1471-1498), un altre artesà-empresari de Cocentaina, també apareix a les tres fonts esmentades: davant el notari compra oli, pren en arrendament el forn de pa del comte de Cocentaina, compra una heretat amb vinyes, olivars i moreres, ven un hort franc, ven l'alqueria d'Albacar (amb cinc famílies de vasalls musulmans), compra una casa franca a la vila, pren en servei a dues joves, i ven una parcel·la franca de cereal; davant el justíca local denuncia que li han furtat un drap d'alt valor que tenia dipositat al molí draper de Bernat Techa; finalment, el seu nom és present als manuals municipals perquè forma part de la juraderia els any 1498 i 1500.

Un sol exemple documental, elegit també entre d'altres que es poden trobar dins aquests fulls del consell de Cocentaina, ens ofereix una destacada i cridanera presència d'artesans i mercaders locals que constantment es fan presents al capdavant de la vila per al seu regiment de la cosa pública: el 22 de desembre de 1498 s'hi reuneix el Consell per fer elecció dels nous càrrecs municipals, i és aleshores quan ens adonem que tant els anteriors oficials com els nous elegits, gairebé tots -quinze prohoms d'un total de dèsset- són artesans o mercaders; i les seues prosopografies ens indiquen a més a més, que estem davant actius professionals de la producció drapera i de la comercialització de tota mena de productes.

\footnotetext{
${ }^{2}$ Els detalls i les referències documentals de la prosopografia d'aquest artesà, i d'altres que hi citarem tot seguit, a Llibrer (2010, vol. II, 26-335).
} 
Consell fonch celebrat dins la cort ordinària de la vila de Cocentayna, en lo qual foren instats los honrats en Bernat Botet (mercader), justícia de la dita vila, e en Gabriel Bosch (paraire), e en Guillem Pèriz, notari, en Martí Johan Pérez de Requena (paraire), e en Nadal Cirera (mercader), jurats de la dita vila en lo present any, $i$ en Johan Sanç (paraire), mustaçaf de la dita vila, e quasi tots los consellers e la major part de la dita vila de pròmens e bons hòmens, per fer elecció de justícia per al any primervinent, e per eleció de albarans ja pus és aceptat ixqueren en elegidors en Jacme Margalit, en Andreu Buera, en Johan Falquó, major de dies, e en Pere Calbo (paraires tots quatre), vehins de la dita vila. Los quals juraren per Nostre Senyor Déu e los sants quatre evangelis de les seus mans corporalment tocats [...], e feren la eleció per a justícia en la forma, manera e les persones infrasegüents: En Bernat Botet, justícia, nomena a·n Loís Johan Calatayud (mercader). En Gabriel Bosch, jurat, a·n Francesc de Leó, major (tintorer). En Guillem Pèriz, notari, jurat, a·n Genís Pérez. En Martí Johan de Requena, jurat, a·n Johan Bosch (tintorer). En Nadal Cirera, jurat, a·n Andreu Buera. En Johan Sanç, mustaçaf, a·n Johan Ferriç. En Jacme Margalit, elegidor, a·n Johan Requena (paraire). En Andreu Buera, elegidor, a·n Pere Andrés. En Johan Falquó, elegidor, a·n Pere Calbo. En Pere Calbo, elegidor, a·n Johan Falquó. Per guàrdia nomenaren a·n Guillem Ferrer (paraire) e Berthomeu de la Tonda (teixidor) ${ }^{3}$.

Al capdavall, la combinació de fonts de diferent origen, però que refereixen a una comunitat relativament menuda, no fan sinò eixamplar les possibilitats per detallar negocis i estratègies sòcio-econòmiques d'aquests petits artesans i mercaders emprenedors, estratègies i negocis que més enllà de la llana o dels draps, anaven cap a d'altres interessos com ara la compravenda de productes agrícoles, de ramat, cap al mercat immobiliari i el mercat del crèdit censal, cap a la inversió en arrendament d'impostos, rendes o monopolis... No definien totes aquestes inversions allò que s'ha anomenat el caire emprenedor d'un home de negocis? Així sembla clar per a d'altres entorns, i ha estat definit fil per randa en casos on la producció drapera esdevé l'arrel d'aquesta capacitat emprendora (Goicolea, 2012). Però, per altra banda, no hi havia en la combinació de tots aquests negocis una estratègia que hui anomenaríem empresarial?

\section{EN PRIMER LLOC, ELS OBRADORS DE DRAPERIA: LLANA I RAMAT}

Paulino Iradiel recordava fa uns anys que la indústria de producció i venda de draps va ser el sector dominant de la manufactura medieval tant per la seua importància qualitativa com pels recursos humans i tècnics que feia servir (Iradiel, 1992, 503); en aquest sentit sembla lògic que fos aquest sector, que necessàriament exigia un ampli col·lectiu d'operadors i la fragmentació detallada dels processos de treball, el que va incorporar i experimentar de forma capdavantera noves formes d'organització de la producció i de la gestió dels recursos emprats (capital, mà d'obra, tecnologia). És per aquesta raó que qualsevol anàlisi que vullga apropar-se a les formes d'empresa d'aquest període, i dins l'àmbit de petites viles i comunitats, ha de passar -i començar- pel sector dels teixits.

3 Arxiu Municipal de Cocentaina (AMC), Manuals de Consell, fol. 21 r. Entre parèntesi hem afegit l'ofici de cada individu, i que hem conegut gràcies a les anàlisis prosopogràfiques (Llibrer, 2010, vol. II, 5-302). 
Al mateix temps, cal recordar que el treball de la llana i d'altres fibres havia estat present de manera tradicional i continuada dins la família camperola; havia esdevingut, en efecte, una activitat complementària per a molts membres de la pagesia (Fernández Trabal, 2004; Llibrer, en premsa). Aquesta inicial manufactura, tancada, domèstica, d'autoconsum, no era desenvolupada per autèntics artesans especialitzas, sinò pels mateixos llauradors que tenien prop les matèries primeres bàsiques -les fibres-, i que sovint no podien completar el conjunt del procés d'elaboració dels teixits amb les fases d'acabat, donant lloc així a uns teixits grollers, de senzilla factura i escassa qualitat. No constituiia per tant, aquesta manufactura casolana, autèntiques empreses artesanals. És cert que aquestes activitats van a suposar amb el temps la base, el substrat necessari, per a l'aparició i el desenvolupament d'autèntiques unitats de producció artesanal especialitzades -és a dir, autèntiques empreses manufactureres $-^{4}$, però açò només era possible si confluïen tota una sèrie de factors associats, com ara la disponibilitat i l'abastiment regular de matèries primeres (llana, però també oli i productes per al tintatge), l'alliberament de mà d'obra procedent de les famílies camperoles gràcies a eficaços sistemes de gestió i a un augment de la producció agrícola, i sobretot, gràcies al mercat consumidor, a la consolidació d'una ampla demanda interna que es podia vehicular mitjançat una xarxa fortament capil-laritzada de vies, enllaços, fires i mercats locals ${ }^{5}$.

Al capdavall, la constitució d'autèntiques empreses artesanals especialitzades en la producció drapera -en qualsevol de les seues nombroses fases-, que és el que realment ens interessa en aquest treball, estarà en íntima relació amb l'àmbit familiar, amb la seua estructura i la seua capacitat interna de treball, tot fent servir molts dels membres que la formaven, i moltes de les iniciatives que l'enllaç, que els enllaços familiars, permetien. És a dir, allò que anomenem l'empresa artesanal aprofitava l'escala familiar per a la seua formació, el seu funcionament i el seu desenvolupament, alhora que aprofitava també totes les potencialitats que les relacions familiars, i de llinatge -i açò serà clau-, permetien (facilitat per a inversions en tecnologia, infraestructura, matèries primeres, etc.).

Sovint s'ha dit que l'empresa artesanal, la unitat de producció manufacturera, naixia amb la família, i açò és cert en la mesura que aquesta unió era la unió de dos patrimonis que, tot i minvats, permetien una mínima inversió inicial per a l'arrencada artesanal. En analitzar l'origen i la inversió de l'empresa drapera, Federigo Melis parlava de la seua escassa inversió bàsica i del seu caire limitat, "l'azienda di Arte Della Lana, anche quando è divenuta independente, quando ha constituido una compagnia, è stata sempre un'azienda di dimensioni modeste in senso reale, como capitale investito; d'altra parte, è da considerare che data la sua organizzazione, non era richiesto un capitale notevole, anche in racione della natura dei fattori produttive" (Melis, 1976, 204). Tot i que l'afirmació no deixa de ser certa quan es aplicada a moltes de les iniciatives manufactureres i draperes, també és cert que la inversió inicial no era menyspreable per a una família d'arrel pagesa, assentada a una comunitat rural o a una petita vila, i la documentació que hem fet servir no deixa de confirmar-nos aquest punt transcendental.

\footnotetext{
4 Aquest procés complex és explicat amb detall per Iradiel (1974, 42-60) i Torras (1981, 7-21).

5 Sobre aquests factors, l'explicació dels quals no és l'objectiu d'aquest article, i la seua influència en la creació d'autèntiques comunitats manufactureres rurals o semiurbanes, ja hem parlat amb detall a d'altres treballs (Llibrer, 2007, 211-2117; Llibrer, 2010, 137-219; Llibrer, 2014, 295-316).
} 
Només amb uns pocs exemples il·lustrarem aquests termes. La documentació judicial, i també la notarial, en mostra amb certa continuïtat l'esforç que suposaven aquestes mitjanes inversions per a moltes famílies artesanals, inversions que molt sovint es traduïen en endeutament. El 1426, després de vuit anys de morositat, Joan de Bas, teixidor veí de Cocentaina, paga a Maria, vídua d'Antoni Tena, també teixidor de la mateixa vila, 209 sous per un teler, un torn de peu i cinc pintes de llana (hun teler de paratge apparellat, hun torn de fust ab son peu, e cinch pintes ab sos arreus d'offici de texidor), que Tena li havia venut en $1416^{6}$. Molts anys després, i també a Cocentaina, el teixidor de llana Pere Amic, acudeix a la taula del notari Guillem Peris per reconéixer un deute de 60 sous amb el teixidor veí Mateu Gonsàlbez, per un teler, unius telari de texir lana ${ }^{7}$; el notari no ens indica quan es cancel·larà el deute, però el fet que s'hi escripture ja es indicatiu de la inseguretat de l'acreedor i de la importància de la quantitat.

Unes senzilles cardes amb el seu suport de fustam per a dur a terme l'operació del cardatge a la perxa del drap, el que permetia alçar el pèl de la llana teixida i així fer-ne una superfície més uniforme i brillant, costaven ja 10 sous a la segona meitat del segle $\mathrm{XV}^{8}$. Tot i que en realitat aquests intruments estaven formats essencialment per una tija de cardes naturals -l'anomenada dipsacus fullonum - amb un arc de fusta, el seu preu esdevenia elevat si pensem que un paraire en feia servir moltes d'aquestes eines durant un any pel fet que l'ampla superfície d'un drap (que segons Furs de València havia de mesurar quaranta-vuit metres de longitud per dos d'amplària ${ }^{9}$ ), exigia el seu cardatge per les dues cares. A més a més, segons la qualitat del drap, aquesta operació havia de repetir-se diverses vegades. Al capdavall, una nova inversió gens menyspreable s'afegia a moltes altres que tenia l'obrador del paraire, per exemple les relacionades amb les instal-lacions del tirador, l'ampli espai on s'estenien els draps per fer l'esmentat cardatge a la perxa: calien els suports, una mena de bastides de fusta que sostenien els pesats draps, també claus, barres i llits baixos on s'anaven doblegant els draps a mesura que eren cardats. Tot açò contribuïa al fet que molts paraires humils acabaren sota la dependència d'altres amb empreses de més capacitat d'inversió i negoci que sí podien fer front a les despeses que suposaven aquests immobles i instal-lacions com ara els tiradors, però també els batans o les almàsseres... (Llibrer, 2014, 324-344). En altres zones manufactureres, com ara algunes ciutats italianes, davant la impossibilitat que la major part dels artesans accediren a la propietat dels tiradors o dels molins drapers, aquests eren construïts i gestionats pel conjunt de la comunitat artesanal o per la corporació (Castagneto, 1996, 176-178).

La necessitat de capital per a l'empresa drapera no era un fet exclusiu de teixidors i paraires, també els abaixadors havien de fer front, per petit i humil que fos el seu obrador,

\footnotetext{
${ }^{6}$ Arxiu de Protocols del Patriarca de València, Col-legi de Corpus Christi, endavant APPV, Sig. núm. 24.813, notari Mateu Pérez, 1426-VII-17.

7 APPV 23.812, Guillem Peris, 1487-XI-27.

${ }^{8}$ En aquestes viles de clara vocació drapera, era necessària la presència d'alguns fabricants de cardes que pogueren subministrar aquests instruments als nombrosos paraires que s'hi concentraven. Segons les nostres anàlisis prosopogràfiques, hem pogut localitzar a la vila de Cocentaina un d'aquests fabricants: es tracta de Bernat de Santafé (1488-1491), qui elaborava i venia aquestes cardes a 10 sous el parell. A més a més, hem pogut conéixer que fabricava uns vint parells de cardes al mes (Llibrer, 2010, vol. II, p. 278).

${ }_{9}$ En efecte, a la rúbrica 142 dels Furs de València, s'hi especifiquen les característiques tècniques que han de tenir obligatòriament els draps de llana elaborats al regne: Cascuna peça de qualque draperia de lana sia haja en longuea XLVIII ales; peça de lana sia de X lliures e pinte de II alnes (López Elum, 1998, 286).
} 
a l'elevada despesa que suposava l'adquisició o fins i tot el lloguer d'unes tisores per al tondosatge dels draps. Al març de 1481, els abaixadors contestans Bernat Ferrer i Bernat Techa reconeixen deure davant notari 130 sous a un tal Joan l'esmolador, pel preu d'unes tisores de baxar. L'any següent, un altre abaixador de la mateixa vila, Guillem Ferrer, nomena procurador al paraire Guillem Vilaplana per a que li reclame a un abaixador d'Alcoi un deute de 160 sous per unes tisores d'abaixar ${ }^{10}$. De nou centenars de sous per adquirir l'instrument bàsic de treball, o de vegades per llogar-lo, cosa freqüent i amplament documentada davant la despesa que suposava (Córdoba de la Llave, 1990, 66). Pensem, a més a més, que calia regularment esmolar les tisores per evitar fer malbé uns draps que estaven a punt d'ésser venuts. I si a aquesta despesa regular, afegim també els grans bancs on treballava l'abaixador, estem de nou davant importants inversions. Fins i tot, com hem vist, la inversió exigia en alguns casos l'actuació conjunta de més d'un artesà, tot intuint relacions professionals entre diferents empreses que sovint es traduïen en la constitució de companyies de capital (Llibrer, 2010, 2011).

I és que fins i tot l'adquisició de les matèries primeres bàsiques per a la draperia, la llana i l'oli, ja exigien una important disponibilitat de numerari que marcava la capacitat productiva de cada artesà i el futur de les diferents empreses draperes. Una arrova de llana -uns 13 $\mathrm{kg}$ - de certa qualitat, per a elaborar draps divuitens i vint-i-uns, els més freqüients localitzas a la nostra zona, tenia un preu mitjà, per a la segona meitat del Quatre-cents, d'uns 20 sous (Llibrer, 2014, 181). Si pensem que per elaborar un drap dels tipus esmentants calia fer servir entre uns 30 i 40 kilos de llana, la despesa mínima només en llana per unitat estaria al voltant d'uns 60 sous. Alhora, mantenir una producció certament constant de draps -pensem que un teixidor necessitava només entre 22 i 25 jornades per al tissatge d'un drap (Hoshino, 1980, 203)- exigia un abastiment continu de llana i, lògicament, una inversió també a l'alçada del ritme de producció desitjat. De fet, la mitjana d'aquisició de llana que hem pogut calcular gràcies a les nombroses compravendes documentades, era realment elevada, d'unes 30 arroves, que permetien elaborar entre set i vuit draps, però que alhora exigien, per part de l'empresa manufacturera, uns 600 sous d'inversió (Llibrer, 2014, 182).

Les estratègies per encarar aquesta despesa, anaven, com en els casos anteriors, des de l'aportació cooperativa entre diversos artesans, a l'adquisició i manteniment de cabanyes ramaderes ovines per part dels paraires i drapers, passant per la subscripció de contractes a mitges amb diversos ramaders per garantir-se el subministrament de llana amb la seua compra anticipada. De totes aquestes tres estratègies empresarials, que de vegades eren complementàries, trobem nombrosos i interessants exemples. Al juny de 1471, dos paraires contestans, Bartomeu Oltra i Bernat Pérez, adquireixen conjuntament 45 arroves de llana, per 720 sous, d'Antoni Espí, de la Vila Joiosa. Un any abans, localitzem dos paraires, un draper i un abaixador de Cocentaina, mentre compren junts anticipadament 90 arroves de llana a Joan Peraleja, de Múrcia, per un preu total de 1.502 sous. De nou el 1471, altres tres paraires contestans viatgen a la Vall de Seta per adquirir tota la llana que durant l'any següent produïsca el ramat d'Azmet Gelut; només un mes després, a la taula del mateix notari Guillem Peris, acudeixen el paraire Bartomeu Oltra, ja esmentat, i el sastre contestà Antoni Sanç, per acordar la compra de forma anticipada de tota la llana que obtinga del seu ramat el llaurador d'Alcoi Bernat Valls. L'any 1481, fins a Penàguila

10 APPV 23.806, Guillem Peris, 1481-III-8 i 23.807, 1482-V-17. 
van els germans Fitor i Guillem Ferrer, paraires veïns, per assegurar-se la llana dels ramats de Mateu Fenollar, a qui ja li paguen anticipadament la quantitat de 850 sous $^{11}$.

Per altra banda, davant la necessitat de garantir-se un subministrament constant de llana per mantindre un cert nivell de producció, i evitar alhora els daltibaixos del mercat d'aquesta estratègica fibra, molts artesans decidiren eixamplar les seues empreses i els seus negocis tot adquirint ramat propi. És evident que aquests artesans, ocupats en la producció dels draps, no podien mantenir les seues cabanyes, que com veurem sobrepassaven sovint els centenars de caps, i per això signaven contractes de cessió o de tinença a mitges amb ramaders de la zona. Es tractava al capdavall de contractes d'arrendament mitjançant els quals l'artesà posava en mans del ramader una determinada cabanya durant un cert temps -normalment de quatre a vuit anys- i amb la partició final de tot allò que produiren els ramats -llana, però també pells, cuirs, carn, llet i derivats (Llibrer, 2010, vol. I, 354-382). El 1474, Bartomeu Pérez, draper contestà, lliurà a mitges -dóna e lliura a miges - a Ucei Casquasi, musulmà de l'Alcúdia, 127 caps de corders per preu de 632 sous:

Berthomeu Perez Monyno dóna e lliura a miges a Ucey Casquasi, moro de l'Alcúdia, terme de Cocentayna, de preu e a ús e costum de bon cabanyer, Cent vint-i-set caps de corders per preu de trenta-una lliures, onze sous, sis diners, en axí deduhit lo dit preu del que s guanyara. E lo dit Ucey, moro, acceptant e rebent aquelles iuxta la continença e dessús deduhida, promet tenir aquelles a tots llur messió e despesa, segons en les dites miges és acostumat ${ }^{12}$.

La breu descripció sobre l'actuació i l'activitat de les dues parts, així com l'ús d'expressions -molt freqüents a la nostra documentació- com a ús e costum de bon cabanyer, segons bon miger acostuma fer, o també segons en les dites miges és acostumat, no fan sinò confirmar l'assiduïtat d'aquestes pràctiques en aquesta zona, i per a aquestes empreses drapreres locals. En febrer de 1472, Bernat Jover, paraire de Cocentaina, posseïx 222 ovelles que cedirà a Mahomat Calciner, Çaat Nage i Mahomat Xativí, de l'alqueria de Benitaer; només cinc mesos després, trobem al draper Bernat Cirera i al paraire Pere Cebrià fent venda a Çaat Acén Citbon, de l'aljama contestana, de 244 borregos, per preu de 976 sous, a raó de 4 sous per cap. En novembre de 1487, Antoni Ripoll, paraire de Cocentaina, cedeix a mitges 60 ovelles a Azmet Aldan, de Fraga, per un preu de 300 sous. A l'octubre de 1498, el draper Joan d'Estanya cedeix durant un any a Mateu de Santamaria, ramader d'Agres, 108 ovelles i 29 cabres, i acorden que al final del període es repartiran la lana, corders e cabrits mascles a miges, e les femelles resten en lo bestiar; però al document següent, d'Estanya li compra a Santamaria tota la llana de la seua part: tota la lana que de sa part Déu li donarà en lo dit bestiar, en lo any sdevenidor e primerament, la qual venda de lana li fa a arova valenciana ab sa tara, e com es acostumat rebre, per lo preu e for que a la tisora se valràn ${ }^{13}$.

Les prosopografies ens han mostrat, a més a més, molts altres artesans tèxtils implicats en la possesió de ramat oví, i tots només entre els anys 1471-1498: l'esmentat Pere

11 Totes les referències documentals a Llibrer (2010, vol. I, 379-382).

12 Arxiu del Regne de València (endavant ARV), Sección Protocolos, nº 1.795, Guillem Peris, 1474IX-3.

13 Les aportacions documentals citades, amb totes les seues dades, i les que farem servir tot seguit, a Llibrer (2010, vol. I, 354-373). 
Cebrià va ser propietari d'almenys 400 caps; el paraire Bernat Figuerola va ser denunciat diverses vegades davant el justícia local -acumulà fins a setze denúncies només l'any $1472-$, perquè la seua ampla cabanya de més de 500 caps envaïa constantment parcel·les i parcel·les del terme; també gràcies a la documentació del Justícia de Cocentaina, hem conegut la nombrosa cabanya del draper Bartomeu Maiques, que sobrepassava els 800 caps: Anthoni Sanç posa clam de Berthomeu Mayques, per ço com dix que ahir li entraren pus de huyt-centes cabeçes de bestiar en los seus mallols a la Plana (1472-IX-30). Al capdavall, paraires i drapers eren en efecte els més implicats en aquests negocis ramaders; en pocs casos hem trobat abaixadors, teixidors, sastres o altres professionals del cicle de la llana, sens dubte amb empreses menys capacitades per a aquestes despeses.

No oblidem, en efecte, que comprar ramat o comprar llana de forma anticipada en grans quantitats, eren en el fons operacions de crèdit pel fet que l'artesà havia d'avançar l'entrega d'un captial al ramader, i no seria fins mesos després quan rebria les matèries acordades. Si fem una ullada al preu mitjà de les ovelles i els moltons en aquesta cronologia -dècades de 1470-1490-, uns 9 sous per a les ovelles i uns 11 sous per als moltons, observem que comprar un centenar de caps suposava una despesa d'al voltant d'un miler de sous. Per altra banda, no només calia un capital per fer l'adquisició, pensem que també era costós mantenir els ramats. Amb les nostres anàlisis, hem calculat que el manteniment d'una cabanya venia a suposar una inversió anual d'1,25 sous per cap (Llibrer, 2010, 368; Llibrer, 2014, 169). En altres paraules, mantenir anualment les 500 ovelles que tenia Bernat Figuerola, li suposava una despesa d'uns 625 sous; al draper Bartomeu Maiques, els seus més de 800 caps li exigien més de mil sous cada any.

Tot plegat no fa sinò explicar que eren només els paraires i drapers més emprenedors, amb empreses més solvents i diversificades -i així ens ho han confirmat les seues prosopografies-, els qui podien apropar-se al mercat de la llana o a la propietat dels ramats. I per aquesta raó, eren aquests emprenedors els qui subministraven la llana als artesans més humils, que no disposaven de la solvència necessària. La documentació no diexa de mostrar-nos constantment aquestes jerarquies entre les empreses draperes, i aquesta distribució interna dels inputs bàsics per a la producció. Humils paraires locals, segons ens ho indiquen també les seues prosopografies, només podien comprar poques arroves de llana als paraires i drapers més solvents: Joan Nogueroles compra 9 arroves a Jaume Panello; l'abaixador Joan de Medina i el paraire Bartomeu Salses compren conjuntament 12 arroves al mercader Ferran d'Andújer; Miquel Lobregat compra 8 arroves al draper Onofre Calatayud; Bartomeu Nogueroles compra només 3 arroves al poderós paraire i draper Bernat Martí (Llibrer, 2010, vol. I, 379-382). Si recordem la quantitat de llana que era necessària per a elaborar un drap, aquestes petites transaccions no fan sinò mostrar la limitada producció de moltes d'aquestes empreses més humils; per altra banda, les escasses activitats que a la documentació i a les prosopografies ens aporten aquests artesans ens confirmen aquesta menor jerarquia empresarial.

\section{EMPRESES DRAPERES: LLANA, PERÒ TAMBÉ OLI}

En parlar de la draperia, sempre referim a la llana com a matèria primera bàsica, però poques vegades hom parla de l'oli com a producte i input clau d'aquesta producció. Recordem que a l'època medieval l'oli tenia importants funcions en l'àmbit domèstic -ali- 
mentació, il·luminació, medicina, neteja- però també en l'àmbit industrial. Per una banda, era necessari com a combustible associat també a la il·luminació; per altra banda, esdevenia cabdal per al manteniment de tota mena de maquinàries -molins de tot tipus i batanscom a element lubricador; era alhora matèria primera bàsica i fonamental per a la producció de sabons i altres substàncies semblants; finalment, es feia servir en diverses fases del treball de la seda i de la llana.

Per una banda, abans de la filatura, durant el cardatge i pentinament inicial de la llana (que servia per separar els flocs, per allargar les fibres i per disposar-les paral-lelament), calia afegir oli a la llana per a que aquesta pogués resistir millor els moviments de les cardes i les pintes. Sabem fins i tot, segons Iradiel, que la llana per elaborar un drap de qualitat, vint-i-quatré (molt semblant als produïts a les nostres viles, que eren divuitens o vinti-uns), exigia uns 10 litres d'oli per a aquestes operacions inicials abans de la filatura (Iradiel, 1974, 191); açò sens dubte ja ens parla de la necessària disponibilitat d'oli i el seu emmagatzematge als obradors domèstics. Per altra banda, també era necessari l'oli una vegada el drap havia estat teixit, tant en el moment del tintatge, per a resoldre algunes de les complexes fòrmules per a sabons, coloració i mordentatge, però sobretot, calia molt d'oli durant el procés de batanatge, quan el drap era sotmés als colps de les maces per a que adquirira el cos i la homogeneïtat desitjada. En aquesta complexa operació, que es duia a terme al molí draper -al batà-, el drap era dipositat a una pila on hi havia una barreja d'aigua i, quasi exclusivament, d' oli.

Tot plegat ens indica que molts artesans -cardadors, tintorers i sobretot paraires (que a la nostra àrea eren amb molta frequiència el gestors o fins i tot els propietaris dels molins drapers)-, havien de fer també importans inversions per adquirir grans quantitats d'oli (Llibrer, 2010, vol. I, 208-209). I de nou, així ens ho mostra repetidament la documentació. De fet, una de les característiques que defineixen, en les nostres anàlisis prosopogràfiques, les empreses més emprenedores és precisament l'activa participació en el mercat de l'oli. I en aquest sentit, destaquen els paraires, els drapers i els tintorers. Fins i tot, podem argumentar que el potent mercat olier d'aquestes comarques, era en bona part dominat pels artesans del tèxtil, com ja hem explicat a d'altres treballs (Llibrer, 2009). En les 80 adquisicions d'oli que hem documentat on intervenen aquests artesans, entre 1470-1500, hem observat que la inversió mitjana era de 600 sous, preu d'unes 70 arroves d'oli (uns 850 litres). És cert que aquestes dades són una mitjana, i com en el cas de la llana, hi trobem també algunes adquisicions més petites, però fins i tot la mínima documentada (6 arroves, uns 73 litres), suposava al voltant d'uns 50 sous. En l'altre sector, el que correspon als artesans amb majors empreses, que acostumen a comprar o vendre oli -perquè no oblidem que actuaven també com a redistribuïdors, igual que amb la llana- trobem transaccions amb xifres sempre properes al centenar d'arroves (uns 1.200 litres): el draper Bartomeu Maiques ven 100 arroves al tender Çaat Maimo en 1471; l'any 1480, el també draper constestà Joan Calatayud ven al tender Axer Alcadí, 200 arroves per un preu de 1.600 sous; el 1487, el paraire de Cocentaina Gabriel Bosch ven a Lluís Alonso, mercader d'Elx, 360 arroves (4.370 litres), amb preu de 2.700 sous; en nou mesos, entre finals de 1491 i principis del 1492, el draper Joan d'Estanya ven 172 arroves a quatre diferents compradors musulmans; en desembre del 1492, el paraire Joan Lobregat compra al tintorer contestà, Pere Maroquí, 150 arroves per 1.050 sous; tres anys després documentem un altre paraire contestà, Bartomeu Oltra, fent una elevada adquisició en el moment que paga 1.200 sous per 200 arroves d'oli al senyor de la Vall d'Alcalà; l'any 1500 Genís Sala, de 
nou un altre paraire de la vila, compra 80 arroves al mercader de València Gaspar Rull, per 300 sous; en novembre de 1516, Bartomeu Iago, paraire veí de Bocairent, compra 54 arroves d'oli (gairebé 700 litres) i paga 300 sous.

Tenia tanta importància la producció i venda d'oli entre els artesans drapers que aquests van acabar controlant també bona part de les almàsseres o els molins d'oli d'aquestes viles. A l'àrea del Comtat fins i tot, van arribar a posseir o gestionar totes les seues almàsseres, les sis que hi havia a Cocentaina, a més de la de Planes i la de Benimarfull (Llibrer, 2010, vol. I, 207-209). Estem davant importants i amplis immobles amb diferents espais i obradors: sala per a la premsa amb rotllos i bigues, pati i habitacions per a l'emmagatzematge tant de l'oliva, com del pinyol, com de l'oli, etc. Els contractes de compravenda o arrendament d'aquestes instal-lacions detallen aquestes característiques que no feien sinó elevar el seu valor. Per exemple, l'amàssera que el paraire Francesc Ripoll tenia a Cocentaina, disposava de:

hun rotlo vell e la biga nova, ab sos arreus, sots del arch de pedra picada que està pegat al cantó de hun graner de metre olives, avall, vers l'ort que fon d'en Jofre Alamany e ara és del dit en Francesc Ripoll, ab la mittat del pati e solar per metre lo pinyol, que està atinent de la dita almàcera...

En realitat aquest paraire tenia una altra almàssera, al costat d'aquesta, i totes dues compartien el pati per al pinyol i l'hort. L'any 1471, Ripoll ven el domini útil de la primera de les seues almàsseres per un preu de 500 sous, i amb l'obligació d'un cens anual de 2 sous i 6 diners ${ }^{14}$.

El protocol d'aquest notari contestà, Miquel Pérez, del que en realitat només en conservem uns pocs quaderns, és molt interessant per conéixer la importància que la producció i el mercat de l'oli tenia en aquests indrets, i la implicació directa del col·lectiu dels artesans drapers. En novembre d'aquest mateix any 1471, hi trobem una altra venda d'almàssera a Cocentaina: aquesta vegada és el llaurador Bernat Grau, tot i que de família de tintorers, com poder saber gràcies a les anàlisis prosopogràfiques, qui ven el domini directe d'una casa almàcera de fer oli, ab un pati per metre lo pinyol, ab tots sos arreus, en la qual hi ha dos rotllos e dos bigues. L'almàssera disposa, per tant, de dos premses, i per aquesta raó el preu és ara de 1.200 sous, i amb un cens emfitèutic de 5 sous i 2 diners anuals; aquest contracte de compravenda ens aporta un altre detall d'interés: el comprador, Alí Rufà, de l'Alcúdia, per pagar part del preu, ven a Bernat dues parcel·les d'olivar, de secà, situades al Camí d'Alcoi, i valorades en 860 sous. L'alt preu assignat als olivars, tot i la seua ubicació al secà, ens parla també del seu estratègic valor. Després parlarem d'aquestes parcel·les en mans dels artesans del tèxtil. Seguint als pocs fulls conservats del nostre notari contestà, trobem, només deu dies després de la venda de la tercera almàssera esmentada, el draper local Joan d'Estanya fent venda de 300 litres d'oli per 240 sous (a for de 10 sous per arrova). En nou dies més, el mateix notari escriptura una altra compravenda d'oli amb protagonistes tèxtils i manufacturers: Francesc Grasso, mestre tintorer contestà, ven 500 litres d'oli per 440 sous (11 sous per arrova) a Çaat Maimo, tender, i a Abdulaziz Alburuc, saboner, tots dos de l'aljama contestana. Al capdavall, en dos mesos, cinc documents diferents on l'oli i els artesans de la llana són protagonistes.

${ }^{14}$ AMC, Secció Protocols, M-42, notari Miquel Pérez (1471-XII-13). 
La producció i el comerç olier genera, per tant, destacats negocis dins les empreses manufactureres.

Però la informació que aporten aquests quaderns no és lògicament l'única que ens permet fer aquestes afirmacions. Qualsevol tipus documental -Manuals de Consell, Cort de Justícia, i altres protocols de l'àrea- no fan sinò mostrar i confirmar la transcendència que l'oli tenia per a les activitats i els negocis dels empresaris drapers. Només una dada aportada per les fonts contestanes per a entendre aquesta importància: entre 1470 i 1500 hem localitzar fins a 79 artesans del tèxtil -paraires, tintorers i drapers essencialment- que tenen relació directa amb la producció i venda d'oli; és a dir, aquests artesans han estat documentats o bé duent a terme transaccions olieres de tota mena, o bé com a propietaris d'almàsseres o de diferents parcel·les d'olivar, o bé en les tres operacions a la vegada. Les anàlisis prosopogràfiques, de nou, ens permeten d'especificar les estratègies empresarials que aquests desenvolupen.

El paraire contestà Gabriel Bosch (1474-1502) és un dels que millor il·lustra aquests negocis. En només 10 dies de març del 1482, arriba a vendre 1.700 litres d'oli a diferents llauradors de la vila de Pego en vuit transaccions; en total, tot i tractar-se de vendes mitjanes (uns 200 litres cadascuna) aconsegueix un benefici de 1.342 sous, i ens recorden que estem davant un redistribuïdor supracomarcal d'oli. No obstant això, aquest paraire que esdevingué mercader -i així ho indicarà la documentació- també distribuirà oli, més endavant, en grans quantitats: al gener de 1487 fa venda a Lluís Alonso, mercader d'Elx, de 4.370 litres, oli que el tender constestà Cale Polopí haurà de transportar fins la capital del Baix Vinalopó. És a dir, aquesta transacció ens deixa entreveure una clara relació professional entre el paraire i el tender musulmà, una mena de senzilla companyia entre tots dos, on l'un aporta les mercaderies i l'altre el seu trasllat. Per altra banda, si el paraire pot vendre aquestes grans quantitats d'oli és perquè lògicament en desenvolupa de forma directa la seua producció, és dir, ha de disposar de nombroses parcel·les d'olivar; i així ho poder confirmar perquè Bosch és senyor de l'alqueria d'Ares, al terme de Penàguila, on bona part de les seues terres de secà estaven dedicades a aquest cultiu.

Però el de Gabriel Bosch no és l'únic cas d'artesans del tèxtil que veuen l'oli com una estratègia clau dels seus negocis, i que ens parlem d'empreses més complexes i diversificades. Del draper contestà Onofre Calatayud (1481-1504) tenim menys dades olieres, però també fonamentals: al gener de 1491 pren en arrendament de forma simultània les dues almàsseres contigües, ja citades, del paraire Antoni Ripoll, per un període de quatre anys i un cens anual de 240 sous; açò li permetrà vendes de gran volada, com la que fa a l'esmentat tender Cale Polopí de 1.214 litres. També trobem el draper Joan d'Estanya (1470-1490) tot fent una desena de vendes olieres a diferents musulmans del Comtat, amb una mitjana de 375 litres (la menor és de 100 i la major de 1.200 litres), i adquirint dues parcel·les d'olivar. El paraire Bartomeu Maiques era propietari de almenys tres parcel·les d'olivar i una almàssera, el que explica tres importants vendes d'oli documentades amb mitjana elevada de 650 litres. Dues parcel·les d'olivar posseïa el tintorer contestà Pere Maroquí (1470-1504), a qui li hem conegut una important venda d'oli (1.820 litres) al paraire veí Joan Lobregat per 1.050 sous. Joan Pérez de Requena (1470-1500), paraire contestà, va ser propietari de dues parcel·les d'olivar més dues heretats franques, una situada al terme de Benimarfull, poblada per famílies musulmanes i amb casa amb almàssera (valorada amb 7.750 sous), l'altra ubicada al terme d'Algars, plantada d'olivars; però a més a més, aquest poderós paraire tenia també una altra almàssera a la vila de Cocentaina. 
Tal vegada el cas amb més implicació oliera d'una empresa artesanal drapera és el del paraire contestà Bernat Martí (1470-1482). Aquest artesà, que començà com a abaixador però que va concloure com a draper, és documentat molt activament en el mercat de l'oli, tot desenvolupant una estratègia empresarial estudiada i modèlica. Inicialment comprava grans quantitats d'oli de forma anticipada, mesos abans de la collita (entre agost i desembre), tot adelantant el preu als venedors: entre agost i desembre del 1474, per exemple, paga anticipadament gairebé un miler de sous a diferents llauradors de la comarca (de Planes, de Catamarruc, d'Almudaina o d'Alcoi) per garantir-se als mesos de gener i febrer un total de 2.380 litres d'oli (que els venedors es comprometen a dur a sa casa en Cocentaina), i amb un preu per arrova de només 4 sous i 6 diners; posteriorment, una vegada aquest paraire-empresari ha emmagatzemat l'oli al seu obrador, fa una intel-ligent vendaredistribució de l'oli que no necessita per a la seua producció tèxtil, durant els mesos centrals de l'any quan la collita ja és escassa, però ara per un preu molt més elevat, amb una mitjana per arrova de 7 sous (de fet, cap als mesos d'octubre a desembre, Martí eleva el preu per arrova fins els 8 sous i 4 diners). Per altra banda, les vendes que fa, a veïns de la vila i la comarca, no són menudes (amb la documentació que hi conservem tenen una mitjana de 773 litres). Fins i tot, podem saber que només entre maig i juny de 1479, per exemple, ven 7.466 litres, i en un sol dia, l'11 de juny d'eixe any, ven 4.080 litres. El benefici d'aquestes transaccions arriba a ser de 3.346 sous. És cert que els beneficis d'aquesta meditada estratègia mercantil són elevats, però també és interessant recordar que calia una important disponibilitat de capital per a les compres anticipades, capital que naixia sens dubte dels ingressos que suposava la producció drapera.

En efecte, no oblidem que tant les adquisicions d'oli, com les de les almàsseres o les parcel·les d'olivar, costosos immobles, suposaven importants despeses que només de nou els artesans més emprenedors, amb empreses més solvents, podien encarar. Oli i llana formaven en efecte un important binomi empresarial. La forta presència de l'oli en l'economia dels obradors manufacturers, de les empreses manufactureres, està en relació, en primer lloc, amb la necessitat d'aquest líquid, d'aquest greix vegetal, en la producció drapera, però hem vist que acabà traduint-se en un important negoci complementari per a molts artesans. I així l'oli esdevé fonamental a l'hora d'analitzar les empreses tèxtils, i essencialment quan intentem determinar la formació, l'organització, i els costos d'aquestes petites i mitjanes empreses.

\section{CONCLUSIÓ: DESCOBRINT PETITES I MITJANES EMPRESES...}

Hem vist com les fonts baixmedievals d'un espai rural o semiurbà com és el Comtat, ens han permés la possibilitat excepcional de reconstruir nombroses estratègies de negoci artesanal, que sens dubte ens han apropat a les iniciatives empresarials. Hem anat a l'estudi de les matèries primeres, als seus costos, a les seues formes -individuals i col-lectives- d'adquisició, també a l'instrumental bàsic d'aquesta manufactura drapera, als mitjans bàsics de producció, i tot per a observar així els nivells qualitatius i tècnics d'aquestes empreses draperes. Uns nivells que ens han mostrat com, lògicament, no totes les empreses, no totes les unitats de producció, estaven en les mateixes condicions per encarar despeses i inversions.

En efecte, si hi ha una conclusió que podem deduir de forma clara i evident és la marcada jerarquització interna que al llarg de tot el segle XV s'hi va anar articulant entre el 
conjunt d'artesans drapers d'aquestes comunitats. Les anàlisis prosopogràfiques ens han permet de diferenciar un petit i "selecte" grup d'empreses més solvents, amb més capacitat d'inversió i negoci (per accedir, per exemple, a la llana en grans quantitats, a la possessió de centenars de caps de ramat o a les almàsseres, o fins i tot a tiradors, batans o tintoreries) (Llibrer, 2012); i per altra banda, la documentació ens deixa també entreveure -de vegades de forma molt subtil, donat que el seu pas per la taula notarial o per les reunions del Consell és força limitat- un ampli grup de petits artesans que al si dels seus obradors desenvolupaven una producció molt limitada, sovint en combinació amb el treball de la terra (eren els agricola et panniparator que apareixen a les fonts), o de vegades sota la influència, sota l'encàrrec, dels artesans més poderosos, dels quals rebien les matèries primeres a canvi del seu treball manufacturer. Tot plegat es traduïa en situacions de dependència envers les famílies i les empreses artesanals més solvents (Llibrer, 2014, 324-332).

Al cim d'aquesta mena de jerarquia empresarial artesanal hi van ubicar-se els paraires i drapers -o millor dit, un grapat d'aquests paraires i drapers- que esdevingueren els gestors o coordinadors que la producció drapera necessitava per connectar tot el conjunt d'artesans i treballadors que exigia el complex i llarg cicle de la llana, des de l'esquilada fins el tintatge, el batanatge o la venda dels draps. Tots dos oficis -paraire i draper- estaven alhora directament relacionats pel fet que la vessant de la producció, la parairia, molt sovint -i hem conegut molts casos, alguns dels quals hem citat- envaïa la vessant mercantil, és a dir, molts paraires emprenedors acabaren enfocant i dirigint les seues empreses cap a les operacions de compravenda de draps, de llana, d'oli... Molts paraires amb el pas dels anys eren designats pels notaris com a "drapers" o fins i tot com a "mercaders". L'origen d'aquests empresaris més actius estava en relació amb les famílies benestants de la pagesia local, que diposaven de recursos per a fer grans inversions en llana, oli, tints, almàsseres, tiradors, batans... Així entenem que no és casual que els grans cognoms dels paraires i drapers siguen també els dels grans llinatges locals, que ja controlaven feia dècades aquestes comunitats rurals, que presidien els seus consells, que esteven al capdavant dels màxims càrrecs locals, que controlaven els monopolis senyorials, els impostos, els molins, les botigues... En el moment la producció drapera esdevé rendible, a causa del significatiu augment de la demanda des de finals del segle XIV, s'apropen a la llana fins arribar a l'especialització dins la parairia tot constituint a poc a poc destacades empreses draperes, empreses que aprofitaven l'embranzida manufacturera amb els petits obradors que sorgien a tot arreu, i amb els quals establien tota mena de relacions de producció (Llibrer, 2010, vol. I, 622-640).

Però tots, uns i altres artesans, els artesans més poderosos i els més humils, conformaven petites o mitjanes empreses. Empreses que tot i el seu caire familiar van permetre l'articulació d'autèntiques economies d'escala i alhora el desenvolupament de moltes viles i àrees rurals de l'interior, que escapaven als grans circuits del poderós comerç internacional. És cert que entre els medievalistes la noció d'empresa es fa servir encara de forma molt limitada i amb desconfiança, però esdevé perfectament lícita, correcta i operativa si pensem que ens referim a una producció comarcal, d'obradors o botigues domèstiques, però on ja hi havia -com hem vist amb els exemples proposats- nombroses iniciatives d'inversió i de negoci amb la circulació de capital o l'associació professional. 


\section{BIBLIOGRAFIA}

AMATORI, F. (2003) (dir.): La storia dell'impresa nella lunga durata: continuità e discontinuità, Venècia, Saggi Marsilio.

CASTAGNETO, P. (1996): L'Arte della Lana a Pisa nel Duecento e nei primi decenni del Trecento. Commercio, industria e istituzioni, Pisa, Gisem, 318 p.

CÓRDOBA DE LA LlAVE, R. (1990): La industria medieval de Córdoba, Córdova, Caja Provincial, $416 \mathrm{p}$.

FERNÁNDEZ TRABAL, J. (2004): "Les indústries rurals", en: Giralt, E. (dir.), Història Agrària dels Països Catalans, vol. II, Barcelona, Universitat de Barcelona, 361-394.

GOICOLEA, F. J. (2012): "Ciudadanos y mercaderes: hacia una caracterización de los hombres de negocios riojanos a fines de la Edad Media", en Bonachía, J. A., Carvajal, D. (ed.), Los negocios del hombre. Comercio y rentas en Castilla. Siglos XV y XVI, Valladolid, Ediciones Castilla, 77-106.

HOSHINO, H. (1980): L'Arte della Lana in Firenze nel Basso Medioevo. Il commercio della lana e il mercato dei panni fiorentini nei secoli XIII-XV, Florència, Leo S. Olschki Editore, 356 p.

IRADIEL, P. (1974): Evolución de la industria textil castellana en los siglos XIII-XVI. Factores de desarrollo, organización y costes de la producción manufacturera en Cuenca, Salamanca, Universidad de Salamanca, $406 \mathrm{p}$.

IRADIEL, P. (1986): "En el Mediterráneo Occidental peninsular: dominantes y periferias dominadas en la Baja Edad Media", Áreas. Revista de Ciencias Sociales, 64-76.

IRADIEL, P. (1992): "Manufactura", en: Diccionario Histórico de la Comunidad Valenciana, València, 505-506.

IRADIEL, P. (2011): "Fuentes de derecho privado: protocolos notariales e historia económica", en: Dove va la storia economica? Metodi e prospettive, sec. XIII-XVIII, Florència, Fondacione Istituto Internazionale di Storia Economica, 2011, 225-248.

LLIBRER, J. A. (2007): Los orígenes de la industria de la lana en la Baja Edad Media. El Comtat en el siglo $X V$, València, Consell Valencià de Cultura, $240 \mathrm{p}$.

LLIBRER, J. A. (2008): "La indústria textil contestana al segle XV. Històries d'artesans i exercici prosogràfic", Alberri, 18, 9-49.

LLIBRER, J. A. (2009): "L'aljama com a espai econòmic: mercaders i artesans mudèjars en l'àmbit contestà", en: Els musulmans al Comtat, Alacant, Diputació-Centre d'Estudis Contestants, 205221.

LLIBRER, J. A. (2010): Industria textil y crecimiento regional: la Vall d'Albaida y el Comtat en el siglo $X V$, tesi doctoral, 2 vols., Departament d'Història Medieval, Universitat de València.

LLIBRER, J. A. (2011): "La formación de compañías para el tintado de paños. El caso de Cocentaina en el siglo XV", Anuario de Estudios Medievales, 41/1, 59-72.

LLIBRER, J. A. (2012): "La gestió dels batans i el desenvolupament de la indústria tèxtil al segle XV. El cas de l'àrea Alcoi-Cocentaina", Estudis d'Història Agrària, 23, 231-248.

LLIBRER, J. A. (2013): “Artesanos ante la justicia. La organización de la industria textil medieval a través de la documentación judicial: el ejemplo contestano (1470-1492)", Historia, Instituciones, Documentos, 40, 123-151.

LLIBRER, J. A. (2014): Industria textil y crecimiento regional: la Vall d'Albaida y el Comtat en el siglo XV, València, Vicerectorat de Projecció Territorial-Departament d'Història Medieval, Universitat de València, $380 \mathrm{p}$.

LLIBRER, J. A. (en premsa): "Pagesos i artesans. Formes d'organització i tipus d'empresa a la manufactura rural (segles XIV-XV)”, en: Pagesia, indústria i món rural. VIII Congrés Sistemes Agraris, Organització Social i Poder Local, Lleida 2013. 
LÓPEZ ELUM, P. (1998): Los orígenes de los Furs de València y de las Cortes en el siglo XIII, València, $303 \mathrm{p}$.

MALANIMA, P. (2003): “Tipi d'impresa prima della crescita moderna”, Annali di Storia dell'Impresa, 14, 159-175.

MELIS, F. (1976): “Gli opifici lanieri toscani dei secoli XIII-XVI”, en: Dini, B. (comp.), Industrie e commercio nella Toscana medievale. Instituto Internazionale di Storia Economica "Francesco Datini” di Prato-Le Monnier (reedició de 1989).

MIRA, A. J. (2000): "La organización de la red molinar en la Vall d'Albaida y l'Alcoià a finales de la Edad Media. Infraestructura industrial, desarrollo económico y fiscalidad”, en: Glick, T., Guinot, E., Martínez, P. (eds.): Els molins hidràulics valencians. Tecnologia, història i context social, València, Diputació, 229-271.

MIRA, A. J. (2005): Entre la renta y el impuesto. Fiscalidad, finanzas y crecimiento económico en las villas reales del sur valenciano (siglos XIV-XVI), València, PUV, 268 p.

NARBONA, R. et alii (1995): L'univers dels prohoms. (Perfils socials a la València baixmedieval), Valencia, Eliseu Climent, 291 p.

NARBONA, R. (1999): "El método prosopográfico y el estudio de las élites de poder bajomedievales", en: El estado de la Baja Edad Media: nuevas perspectivas metodológicas, 31-49.

NAVARRO, G. (1999): Los orígenes de la sedería valenciana (siglos XV-XVI), València, Ajuntament de València, $333 \mathrm{p}$.

NAVARRO, G. (2003): "La industria textil en los reinos de Aragón y Valencia en la Edad Media", en: XVII Congrés d'Història de la Corona d'Aragó, Barcelona, 476-491.

NAVARRO, G. (2000): "Los negocios de la burguesía en la industria precapitalista valenciana de los siglos XIV-XV”, Revista d'Història Medieval, 11, 67-103.

NAVARRO, G. (2013): "Les industries rurales dans la Couronne d'Aragon au XV siècle", en: Vinovez, J. M., Verna, C. i Hilaires-Perez (dirs.), Les industries rurales dans l'Europe médiévale et moderne, Toulouse, Presses Universitaires du Mirail, 89-112.

NAVARRO, G. (2014): "La política de desarrollo de las manufacturas textiles en la Corona de Aragón”, en: Tanzini, L., Tognetti, S. (ed.), Il governo dell'economia. Italia e Peninsola Iberica nel baso Medioevo, Roma, Viella, 285-308.

TORRAS, J. (1981): "Estructura de la indústria precapitalista. La draperia", Recerques, 11, 7-28.

VERNA, C. (2013): "Pour une approche biographique de l'entreprise rurale au Moyen Âge", en: Vinovez, J. M., Verna, C. i Hilaires-Perez (dirs.), Les industries rurales dans l'Europe médiévale et moderne, Toulouse, Presses Universitaires du Mirail, 77-88. 
